\title{
PRELIMINARY REPORT TO THE CANADIAN SOCIETY OF FOREST ENGINEERS ON THE FORMING OF SECTIONS
}

\author{
C. D. Howe
}

Unfortunately I have been unable to correspond with as many mem. bers of the Society as I would have liked regarding the formation of sections in different parts of Canada and particularly in the Prairie Provinces. The following list is therefore only a suggested arrangement, and I hope the members will feel free to criticize it and make any changes they consider necessary.

1. British Columbia Section:

This section would include all foresters in British Columbia. Incidentally I might say that this section has been functioning as such for at least two years and if it has not already been done, I would recommend that this section be officially recognized by the Society.

\section{Prairie Provinces Section:}

This section will include all the foresters of the Prairie Provinces. It would mean that it would cover a large area of country and possibly the men in that section of Canada would like to have two or more sections instead of one.

\section{Northern Ontario Section:}

This would include all foresters in Ontario north and west from North Bay.

4. Southern Ontario Section:

This would include all foresters south of North Bay and east as far as Tweed, taking in the City of Toronto.

\section{Eastern Ontario Section:}

This would include all foresters in the eastern section of Ontario, taking in the City of Ottawa.

\section{Quebec Section :}

This would include all foresters in the Province of Quebec.

\section{Maritime Section:}

This would include all foresters in the Maritime Provinces.

If the above arrangement of sections is decided upon, or whatever list is adopted, it will then be necessary for someone in the Society to correspond with key men in these different sections of the country and proceed with the forming of each section providing the members there are favorable. 